146

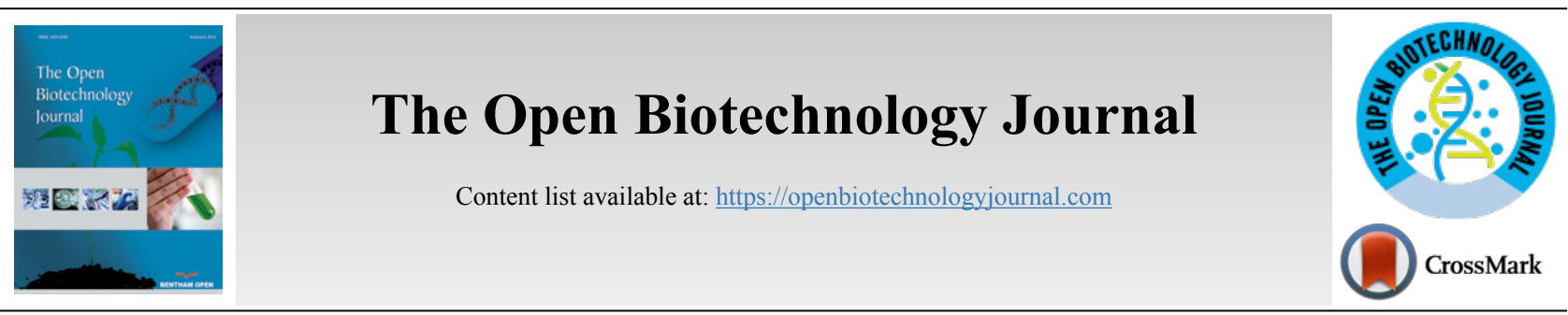

RESEARCH ARTICLE

\title{
Development of MNPs Based Enzyme Immuno-Sorbent Analysis for the Determination of Organophosphorus Pesticides in Milk
}

Yavor Ivanov ${ }^{1, *}$

${ }^{\prime}$ Department of Biotechnology, "Prof. Dr Assen Zlatarov” University, Burgas, Bulgaria

\begin{abstract}
:
Objectives:

High toxicity of pesticides requires accurate and reliable methods to monitor their levels for food, water and soil safety.

Methods:

Magnetic nanoparticles were synthesized and functionalized with (3-aminopropyl)triethoxysilane. Sheep polyclonal-anti-paraoxon and antidichlorvos antibodies were produced. Dichlorvos-cationized ovalbumin-HPR and paraoxon-ovalbumin-HPR conjugates were prepared and characterized. The optimal conditions for antibody immobilization were determined. Enzyme immunosorbent assay based on Magnetic Nanoparticles (MNPs) for the determination of pesticides was developed. A comparison of the developed modified MNPs-based ELISA with the conventional ELISA was performed. The effect of protein, $\mathrm{pH}$, and fats in milk samples on the analytical characteristics of the MNPs-based ELISA was investigated. In order to validate the results obtained from the MNPs-based ELISA method, experiments with HPLC were performed.

Results:

The linear range of the standard curve for the determination of paraoxon in buffer with anti-paraoxon antibody was $0.125-5 \mathrm{ng} / \mathrm{mL}$, for the dichlorvos with anti-dichlorvos antibody was $0.0625-5 \mathrm{ng} / \mathrm{mL}$, and for the mixture of paraoxon and dichlorvos in ratio (1:1) with multi-antibody was $0.125-5 \mathrm{ng} / \mathrm{mL}$. A comparison of the developed modified MNPs-based ELISA with the conventional ELISA was performed. The recovery of the obtained results for the determination of pesticides in milk samples in both methods was from 104 to $110 \%$.

Conclusion:

The stated advantages of magnetic nanoparticles provide good sensitivity and rapidity of immunoassay and a simple procedure for separating of antibody-magnetic nanoparticles with the bound antigen from the non-bound antigen in the sample.
\end{abstract}

Keywords: Pesticides, Polyclonal antibody, Magnetic nanoparticles, Enzyme immuno-sorbent analysis, Milk, ELISA method.

\begin{tabular}{|c|c|c|c|}
\hline Article History & Received: April 25, 2019 & Revised: July 24, 2019 & Accepted: October 13, 2019 \\
\hline
\end{tabular}

\section{INTRODUCTION}

Pesticides play an important role in agriculture, but they are one of the most important environmental pollutants because of their spread in water, soil, atmosphere, and agricultural products. Pesticides are dangerous to human health. Different pesticides have different acceptable residual levels that are defined by the World Health Organization (WHO), the European Community (EU), the FAO (the Organization for Food and Agriculture) of the United Nations [1]. Recently, organophosphorus pesticides find application because they are

* Address correspondence to this author at the Department of Biotechnology, "Prof. Dr Assen Zlatarov" University, Burgas, Bulgaria;

E-mail: qvor_burgas@abv.bg more easily degraded [2]. They break down rapidly in plants and animals, forming less toxic metabolites [3, 4]. High toxicity of pesticides requires accurate and reliable methods to monitor their levels for food, water, and soil safety [5]. Chromatographic methods (gas chromatography, high performance liquid chromatography combined with mass spectrometry, etc.) are effective for the determination of pesticides [6]. They are sensitive and reliable but have also some disadvantages such as expensive equipment, they require a well-trained specialist, considerable time for sample preparation, inability to work under field conditions, etc. To avoid these shortcomings, other techniques and methods have also been developed - chemical sensors, biosensors, spectroscopic techniques, immunochemical methods, etc. 
Immunochemical methods of analysis are based on the binding of an antigen molecule (pesticide) to specific antibodies and are increasingly used for the determination of pesticides in different samples [7]. The conducted assays may be individual using one antibody or multiplex using several antibodies. When using a multi-hapten strategy, several antibodies are produced simultaneously in one animal $[8,9]$. Because the production of polyclonal antibodies is a slow process, this strategy has advantages. When several antigens are mixed, a multi-hapten immunogen is formed to produce multipolyclonal antibodies that in terms of quality match the individual antibodies $[10,11]$. Immunological analyses are a rapid method of screening samples. Unlike chromatographicbased methods, they are simple, specific, easy to use, high performance, and do not require costly appliances. This makes them suitable for field work and quick screening. From immunological analyzes, the most commonly used is EnzymeLinked Immunosorbent Assay (ELISA), which combines the unique immunoassay specificity with the high sensitivity of an enzyme marker. A number of ELISAs for detecting pesticides have been developed [12 - 14]. Currently, some food manufacturers use rapid ELISA tests to make sure that the products they buy do not have illegal residues of some pesticides [15 - 17].

The use of magnetic nanoparticles in combination with ELISA leads to the elimination of nonspecific binding and preserves the activity of the immobilized antibody over time. MNPs have a high specific surface area and provide good contact between the immobilized antibody and the antigen and correspondingly high rate of immunoreaction $[18,19]$. The advantages of magnetic nanoparticles have led to the development of an integrated method to provide better sensitivity, short immobilization time, rapid analysis, and simple washing procedures. There are few developed MNPs ELISA assays for determining zearalenone, ochratoxin, aflatoxin B1 [20 - 23], but there are no such assays for determination of pesticides. Immunological methods are very suitable for milk analysis. Since milk is a liquid, milk samples can be analyzed directly or only after simple pre-treatment, such as dilution. For this reason, immunoassays used for the study of chemical pollutants, including pesticides in milk, are causing considerable attention in recent years [24, 25]. Ethyl paraoxon is very toxic and has never been registered for use as a pesticide. Ethyl paraoxon is formed in the environment from the oxidation of ethyl parathion. Ethyl parathion and dichlorvos are used in agriculture.

The aim of the present study is to develop and compare a rapid and sensitive immunosorbent assay based on magnetic nanoparticles and/using individual and multi-polyclonal antibody for individual and simultaneous determination of organophosphorus pesticides dichlorvos and paraoxon.

\section{MATERIALS AND METHODS}

\subsection{Reagents}

For the preparation of cationized Bovine Serum Albumin (cBSA), were used bovine serum albumin (BSA), 1-ethyl-3-[3dimethylaminopropyl] carbodiimide hydrochloride, and ethylenediamine, purchased from Sigma-Aldrich (Taufkirchen,
Germany). The used reagents for obtaining of conjugates - 2,2dichlorovinyl dimethyl phosphate (DDVP), paraoxon-ethyl (diethyl 4-nitrophenyl phosphate), ovalbumin (OVA), formaldehyde, diethyl ether, hydrochloric acid, acetic acid, sodium chloride, ethyl acetate, glutaraldehyde, zinc powder, anhydrous sodium sulfate, dimethyl formamide, horseradish peroxidase (HPR) were purchased from Sigma-Aldrich (Taufkirchen, Germany). Bradford reagent and 3,3,5,5'tetramethylbenzidine were also bought from Sigma-Aldrich (Taufkirchen, Germany).

\subsection{Instrumentation}

The 96-well polystyrene high-binding microtiter plates from TPP Switzerland were used for ELISA. Plates were processed using an RT $2100 \mathrm{C}$ Rayto microplate reader. The determination of pesticides was also performed by highperformance liquid chromatography for comparison. An Agilent Series 1100 high-performance liquid chromatograph 120 was used in these studies.

\subsection{Solutions}

The coating buffer was $50 \mathrm{mM}$ carbonate buffer ( $\mathrm{pH}$ 9.6). The phosphate buffer saline was $10 \mathrm{mM}$ phosphate buffer $(\mathrm{pH}$ 7.4) containing $145 \mathrm{mM} \mathrm{NaCl}$. The blocking solution was phosphate-buffered saline with $1 \%$ bovine serum albumin. The horseradish peroxidase conjugate solutions were prepared by dissolving different amounts of conjugates in phosphatebuffered saline containing $0.5 \%$ bovine serum albumin. The washing buffer was phosphate-buffered saline with $0.05 \%$ Tween-20. The substrate solution was prepared by mixing of $4.5 \mathrm{~mL} 50 \mathrm{mM}$ citrate buffer $\mathrm{pH} 5,0.5 \mathrm{~mL} 1 \mathrm{mg} / \mathrm{mL} \mathrm{3,3',5,5^{ \prime } -}$ tetramethylbenzidine (TMB) in dimethylformamide and $15 \mu \mathrm{L}$ of $30 \% \mathrm{H}_{2} \mathrm{O}_{2}$.

\subsection{Preparation of Functionalized MNPs, Polyclonal Anti- paraoxon, Polyclonal Anti-DDVP and Multi-polyclonal Antibodies}

The preparation and functionalization of MNPs with (3aminopropyl)triethoxysilane (APTES) were carried out by methods described in our previous paper [26]. The production of anti-paraoxon and anti-DDVP antibodies was carried by immunization of sheep with paraoxon-BSA and dichlorvoscBSA. The method was described in our previous paper [27]. Multi-polyclonal antibodies were prepared by immunization with the mixture of paraoxon-BSA and dichlorvos-cBSA in ratio $1: 1$, described in the same paper.

\subsection{Preparation of Dichlorvos-Cationized Ovalbumin-HPR and Paraoxon-Ovalbumin-HPR Conjugates}

The conjugation of dichlorvos-cationized ovalbumin and paraoxon- ovalbumin was performed by the methods described earlier [27]. The dichlorvos-cationized ovalbumin-HPR and paraoxon-ovalbumin-HPR conjugates were prepared by using glutaraldehyde. Pesticide-ovalbumin $(3 \mathrm{mg}$ ) was dissolved in $500 \mu \mathrm{L}$ deionized water containing $1 \%$ glutaraldehyde. The mixture was incubated for $1 \mathrm{~h}$ at room temperature. Then, a solution of $2 \mathrm{mg}$ horseradish peroxidase in $200 \mu \mathrm{L}$ deionized water was added to the mixture and incubated overnight at $4^{\circ} \mathrm{C}$. 
The conjugates were purified by a Sephadex G-25 column $(1 \times 20 \mathrm{~cm})$. The optical density of the obtained conjugates was measured at a wavelength of $403 \mathrm{~nm}$ using a Jenway 6900 ultraviolet-visible spectrophotometer. The conjugates were freeze-dried.

\subsection{Determination of the Optimal Conditions of Antibody Immobilization}

The optimal immobilization conditions of the antibody were examined by varying the incubation time (2, 8 and $15 \mathrm{~h})$ and temperature $(4,15,25$ and 35C). MNPs $(5 \mathrm{mg})$ and $1 \mathrm{~mL}$ antibody solution $(1 \mathrm{mg} / \mathrm{mL}$ in $10 \mathrm{mM}$ PBS $\mathrm{pH} 7.4)$ were allowed to react at these conditions. The amount of immobilized antibody on MNPs was determined by the Bradford method [28], on the basis of the difference between the initial amount of protein in the antibody solution and the resulting excess after immobilization.

\subsection{Antibody Immobilization on MNPs at Optimal Conditions}

The functionalized MNPs $(5 \mathrm{mg}$ ) were collected with a magnet, nanoparticles were resuspended in $1 \mathrm{~mL}$ glutardialdehyde solution $(5 \% \mathrm{w} / \mathrm{v}$ in $50 \mathrm{mM}$ PBS $\mathrm{pH} 8)$ and incubated for $2 \mathrm{~h}$ at room temperature with orbital agitation. Then, the nanoparticles were washed once with $50 \mathrm{mM}$ PBS $\mathrm{pH} 8$ and five times with $10 \mathrm{mM}$ PBS pH 7.4. MNPs were resuspended in $1 \mathrm{~mL} 10 \mathrm{mM}$ PBS pH 7.4 containing antibody with the following concentrations $(0.1,0.4,0.7,1.0,1.5$ $\mathrm{mg} / \mathrm{mL}$ ) and incubated for $2 \mathrm{~h}$ at $37^{\circ} \mathrm{C}$. After that, the nanoparticles were washed three times with $10 \mathrm{mM}$ PBS pH 7.4 and the free active $\mathrm{NH}_{2}$ groups were blocked by adding 10 mM PBS pH 7.4 containing 1\% BSA and $0.05 \%$ Tween 20 . The mixture was stirred for $1 \mathrm{~h}$ at room temperature, washed three times, and resuspended in the same buffer to a final concentration of $5 \mathrm{mg} / \mathrm{mL}$. The mean amount of immobilized antibody on MNPs in all antibody immobilizations was determined by the Bradford method.

\subsection{Principle of Enzyme Immunosorbent Assay Based on MNPs}

The MNPs-ELISA method is based on the principles of competitive immunoassay. The immobilized antibody onto the MNPs is prepared in greater quantity. The sample containing the antigen (the pesticide) is added to a certain portion of the antibody and the mixture is incubated for 15 minutes. At this stage, the antibody recognizes the antigen and binds it specifically. Enzyme-labeled antigen (competitive conjugate) is then added and the mixture is incubated for a further $15 \mathrm{~min}$ to bind the conjugate to the free antigen-binding sites of the immobilized antibody. After each of these two steps, washing is performed to remove excess antigen and conjugate also by the aid of magnetic separation. Finally, a substrate solution (tetramethylbenzidine - TMB) is added, the mixture is incubated for $15 \mathrm{~min}$, the enzyme reaction is stopped with acid, magnetic separation is performed, and the color intensity of the solution is measured at $450 \mathrm{~nm}$ wavelength with the ELISA reader. When the the concentration of the pesticide is high, the less conjugate will bind to the immobilized antibody and the intensity of the coloration will be lower and vice versa.

\subsection{Determination of the Optimal Conditions for Carrying Out an Immunosorbent Assay Based on MNPs for the Determination of Paraoxon-Ethyl and Dichlorvos}

The optimal concentration of the conjugates for the conduction of the enzyme reaction was determined. The concentrations of paraoxon-OVA-HPR and DDVP-cOVAHPR conjugates were varied $(0-4 \mu \mathrm{g} / \mathrm{mL})$. The concentration of substrate was constant $0.1 \mathrm{mg} / \mathrm{ml}$. To $20 \mu \mathrm{L}$ of conjugate was added $50 \mu \mathrm{L}$ of the substrate and the enzymatic reaction was conducted at room temperature for 15 minutes at dark. The reaction was ceased by adding $50 \mu \mathrm{L}$ of $2 \mathrm{M} \mathrm{H}_{2} \mathrm{SO}_{4}$ and the color intensity was measured at a wavelength of $450 \mathrm{~nm}$ with a Microplate reader RT 2100C.

In order to determine the optimal antibody concentration for immunoreaction, the antibody concentration ranges from 0.005 to $0.05 \mathrm{mg} / \mathrm{mg}$ MNPs. To $20 \mu \mathrm{L}$ of the conjugate $(0.1 \mathrm{mg}$ / $\mathrm{mL}$ ), $50 \mu \mathrm{L}$ of immobilized antibody on MNPs with indicated concentrations was added. The mixture was incubated for 15 minutes at $37 \mathrm{C}$. Then, the magnetic nanoparticles with the formed conjugate were washed five times with $10 \mathrm{mM}$ phosphate buffer solution with $0.05 \%$ Tween $20(\mathrm{pH} 7.4)$. Then, $50 \mu \mathrm{L}$ of the substrate solution was added to the formed complex and incubated at room temperature for $15 \mathrm{~min}$ in the dark. The reaction was stopped and the color intensity was measured at a wavelength of $450 \mathrm{~nm}$.

\subsection{Enzyme Immunosorbent Assay Based on MNPs for Determination of Paraoxon-Ethyl and Dichlorvos in Buffer Solutions}

After the establishment of optimal concentration for conjugate and antibody, the calibration curves were plotted by using different concentrations of pesticide in buffer solution. $50 \mu \mathrm{L}$ solution of immobilized antibody onto magnetic nanoparticles with the concentration of $0.025 \mathrm{mg}$ per $\mathrm{mg}$ magnetic nanoparticle was added to $50 \mu \mathrm{L}$ of each sample with different pesticide concentrations $(0.01$ to $10 \mathrm{ng} / \mathrm{mL}$ in $10 \mathrm{mM}$ phosphate buffer solution, $\mathrm{pH}$ 7.4) and were incubated for 15 min. Then, magnetic nanoparticles were collected by a magnetic field of $10,000 \mathrm{G}$ and washed with $10 \mathrm{mM}$ phosphate buffer solution $\mathrm{pH} 7.4$, contained $0.05 \%$ Tween 20 . After that the antigen-peroxidase conjugate $20 \mu \mathrm{L}(0.1 \mathrm{mg} / \mathrm{mL})$ was added, and the mixture was incubated for $15 \mathrm{~min}$. Then the substrate reaction was performed by the methodic described in the previous point. The simultaneous determination of paraoxon and dichlorvos in ratio 1:1 with multi-polyclonal antibody was carried out the same way like the assay of the individual antibody.

The experimental signal (Y) was calculated using the following equation:

$$
Y=B / B \times 100, \%
$$

B - Absorbance of the sample containing analyte concentration

B - absorbance of blank sample (no analyte present)

2.11. Conventional Competitive ELISA for the Determination of Paraoxon-ethyl and Dichlorovos in Buffer Solutions

The concentration of antibody and coating antigen was 
optimized by a checkerboard titration. A total volume of 100 $\mu \mathrm{L}$ of each hapten-ovalbumin conjugate $(1 \mu \mathrm{g} / \mathrm{mL}$ in coating buffer) was added to wells of the microtiter plate at $4^{\circ} \mathrm{C}$ overnight. In case with multi-polyclonal antibody, the mixture of conjugates dichlorvos-cationized ovalbumin and paraoxonovalbumin 1:1 (100 $\mu \mathrm{L}$ total volume) was added. Then the wells were washed three times with washing buffer. After that $200 \mu \mathrm{L}$ of blocking buffer was added and incubated at $37^{\circ} \mathrm{C}$ for $1 \mathrm{~h}$. The wells were washed four times with washing buffer. 50 $\mu \mathrm{L}$ of the pesticide standards ( 0.01 to $10 \mathrm{ng} / \mathrm{mL}$ in buffer) and $50 \mu \mathrm{L}$ per well antibody $(50 \mu \mathrm{g} / \mathrm{mL}$ in phosphate-buffered saline) were sequentially added to the wells and allowed to react at room temperature for $1 \mathrm{~h}$. After washing five times with washing buffer, the next step was adding the substrate like in the above protocol.

\subsection{Recovery of Pesticides in Milk by MNPs-based ELISA and Conventional ELISA}

The recovery of pesticides in cow's milk was evaluated. Milk samples, free from pesticides, were spiked with $0.1,0.5$, and $4 \mathrm{ng} / \mathrm{mL}$ dichlorvos and paraoxon-ethyl. The concentrations of the pesticides in milk samples was estimated by the MNPs-based ELISA and the conventional ELISA.

\section{RESULTS AND DISCUSSION}

\subsection{Determination of the Optimal Conditions for Antibody Immobilization on MNPs}

Modified magnetic nanoparticles with 3-(aminopropyl) triethoxysilane were used as carriers for the covalent immobilization of the anti-paraoxon antibody and the antidichlorvos antibody. After the treatment of MNPs with APTES, amino groups were introduced at their surface. These groups were activated with glutaraldehyde, the molecule of which contains two aldehyde groups. One aldehyde group binds to the amino group of MNPs, and the other reacts with the amino group of the lysine residue of the antibody. As a result of these reactions, Schiff bases were formed, and the antibody was covalently immobilized on MNPs.

One of the most important conditions for the immobilization of the bioagents is to determine the optimal concentration of the antibody initial solution. The influence of the concentration of the antibody solution on the degree of antibody immobilization was investigated (Fig. 1). A progressive increase in the amount of bound antibody is observed with an increase in the antibody concentration ( 0.4 to $1 \mathrm{mg} / \mathrm{mL}$ antibody). Upon further increase in antibody concentration over $1 \mathrm{mg} / \mathrm{ml}$, surface saturation of MNPs with antibody was observed (Fig. 1).

The influence of incubation conditions of the antibody on MNPs has also been studied. For this purpose, the time and temperature are varied. MNPs $(5 \mathrm{mg})$ and antibody $(1 \mathrm{mg} / \mathrm{mL})$ was allowed to react at temperature $4,15,25$ and $35^{\circ} \mathrm{C}$. The incubation time was also varied $-2,8 \mathrm{~h}$ and overnight. The higher degree of immobilization was received at 25 and $35^{\circ} \mathrm{C}$ (30 $\mu \mathrm{g} / \mathrm{mg}$ MNPs). The bound antibody was $30 \mu \mathrm{g}$ per $1 \mathrm{mg}$ MNPs after overnight incubation, whereas for 2 and $8 \mathrm{~h}$ incubation, the bound antibody was $28 \mu \mathrm{g}$ per $1 \mathrm{mg}$ of MNPs.
The results obtained show that due to the high specific surface area of the magnetic nanoparticles, the antibody immobilization rate was high and the equilibrium was reached within 2 hours.

\subsection{Determination of the Optimal Conditions of MNPs Based ELISA for Separate and Simultaneous Determination of Dichlorvos and Paraoxon}

The optimal concentration of the two competitive conjugates diclorvos-ovalbumin-HRP and paraoxonovalbumin-HRP required to conduct the enzyme reaction between the peroxidase and the tetramethylbenzidine was determined. A series of dilutions of the conjugate were made from 0 to $4 \mu \mathrm{g} / \mathrm{mL}$. Fig. (2) shows that the optimal conjugate concentration is $1 \mu \mathrm{g} / \mathrm{mL}$. The optical density after this concentration is almost constant at the selected substrate concentration $(0.1 \mathrm{mg} / \mathrm{mL})$. If the substrate concentration is higher than the chosen value, the color of the solution changes (from blue to green) and the results are not reproducible.

The optimal concentration of two immobilized antipesticide antibodies for the performance of immunoassay was determined. Serial analyses with different concentration of immobilized anti-paraoxon and anti-dichlorvos antibody (Fig. 3) were carried out with the optimal concentration of two conjugate antigen-ovalbumin-peroxidase conjugate $(1 \mu \mathrm{g} / \mathrm{mL})$ and $0.1 \mathrm{mg} / \mathrm{mL}$ substrate solution. The graph was plotted as optical density against the amount of the immobilized antibody on MNPs. The results are presented in Fig. (3). It is determined that the optimal amount of immobilized antibody is $0.025 \mathrm{mg}$ per mg magnetic nanoparticles.

\subsection{Basic Analytical Characteristics of MNPs-Based ELISA for Separate and Simultaneous Determination of Dichlorvos and Paraoxon-Ethyl}

On the basis of the optimal antibody and labeled antigen concentrations, an MNPs-based ELISA method was developed to determine the concentration of paroxon-ethyl and dichlorvos separately and simultaneously in the same sample. Experiments are performed with standard solutions of pesticides. Fig. (4) shows the calibration curves of paraoxon and dichlorvos in the buffer. The number of analysis at each concentration was six. It was found that the linear range of the standard curve for the determination of paraoxon in buffer with anti-paraoxon antibody was $0.15-5 \mathrm{ng} / \mathrm{mL}$, for the dichlorvos with antidichlorvos antibody was $0.063-5 \mathrm{ng} / \mathrm{mL}$, and for mixture paraoxon and dichlorvos with ratio (1:1) with multi-antibody was $0.15-5 \mathrm{ng} / \mathrm{mL}$. The obtained results with multi-antibody were very close to the results with separate antibody and these results showed that no non-specific reaction occurred in the preparation of multi-polyclonal antibodies. For the production of polyclonal antibodies the purity of the hapten is very important to obtain antibody without non-specific reaction. The high purity of the used haptens and hapten-protein conjugates [27] ensured specific reactions between antibodies and antigens. The sensitivity of the analysis is usually expressed by its detection limit and the slope of the linear range of the standard curve. The detection limit (LOD) is the lowest concentration of the analyte, giving a statistically different response to that observed in the absence of an analyte and is 
calculated as $95 \%$ of B (the absorption intensity of the bound conjugate to the immunosorbent in the absence of the pesticide). The sensitivity of the dichlorvos assay in buffer was found to be higher than the other two assays, LOD is two times lower than the LODs of the other two assays. For all analyses, a good reproducibility of the results was obtained - coefficients of variation $(\mathrm{CV}, \%)$ varied from 6.6 to $7.5 \%$.

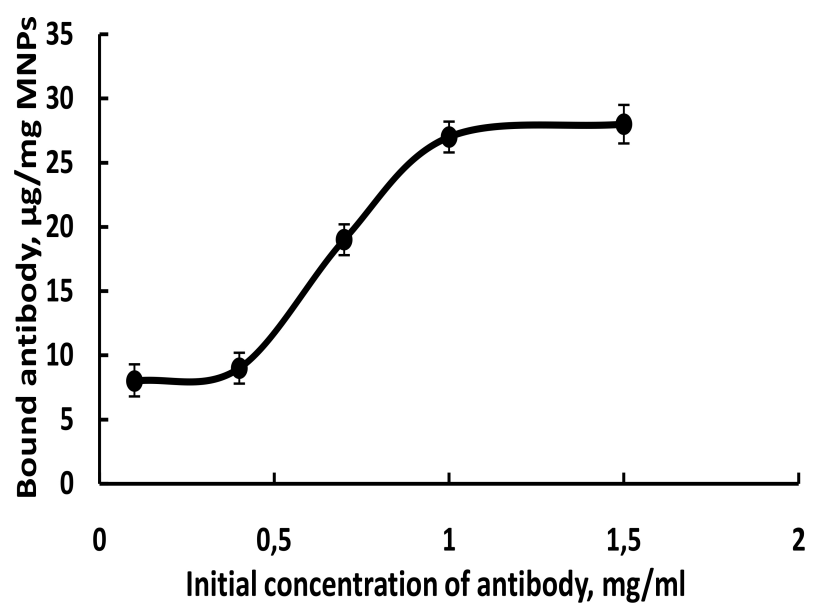

Fig. (1). Dependence between the concentration of initial antibody solution used for immobilization and the amount of antibody bound to MNPs.

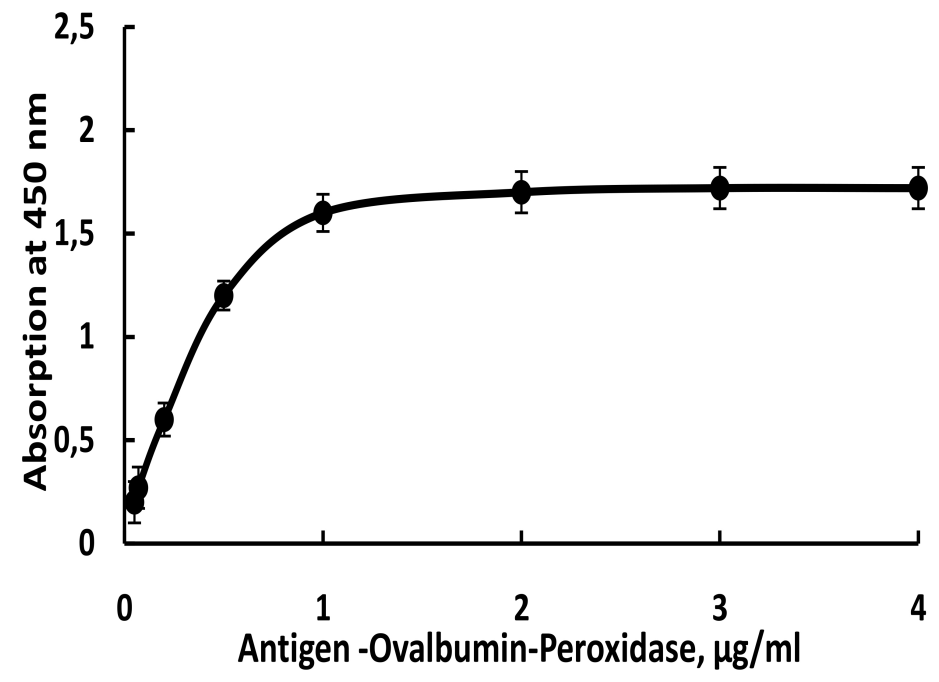

Fig. (2). Influence of antigen-ovalbumin-peroxidase concentration on the analytical signal intensity.

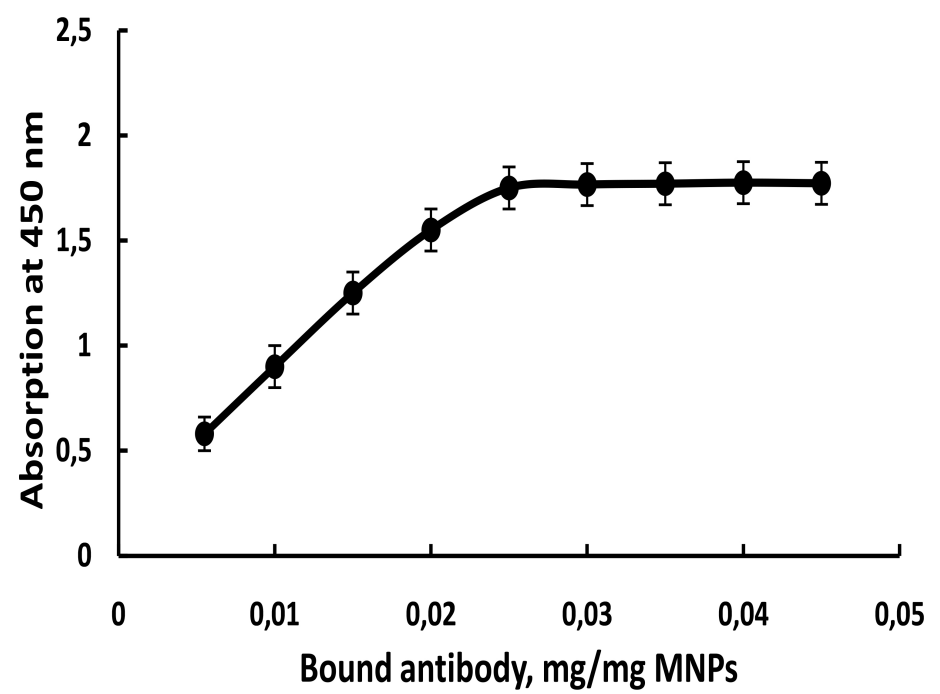

Fig. (3). Effect of immobilized antibody concentration on the analytical signal intensity. 


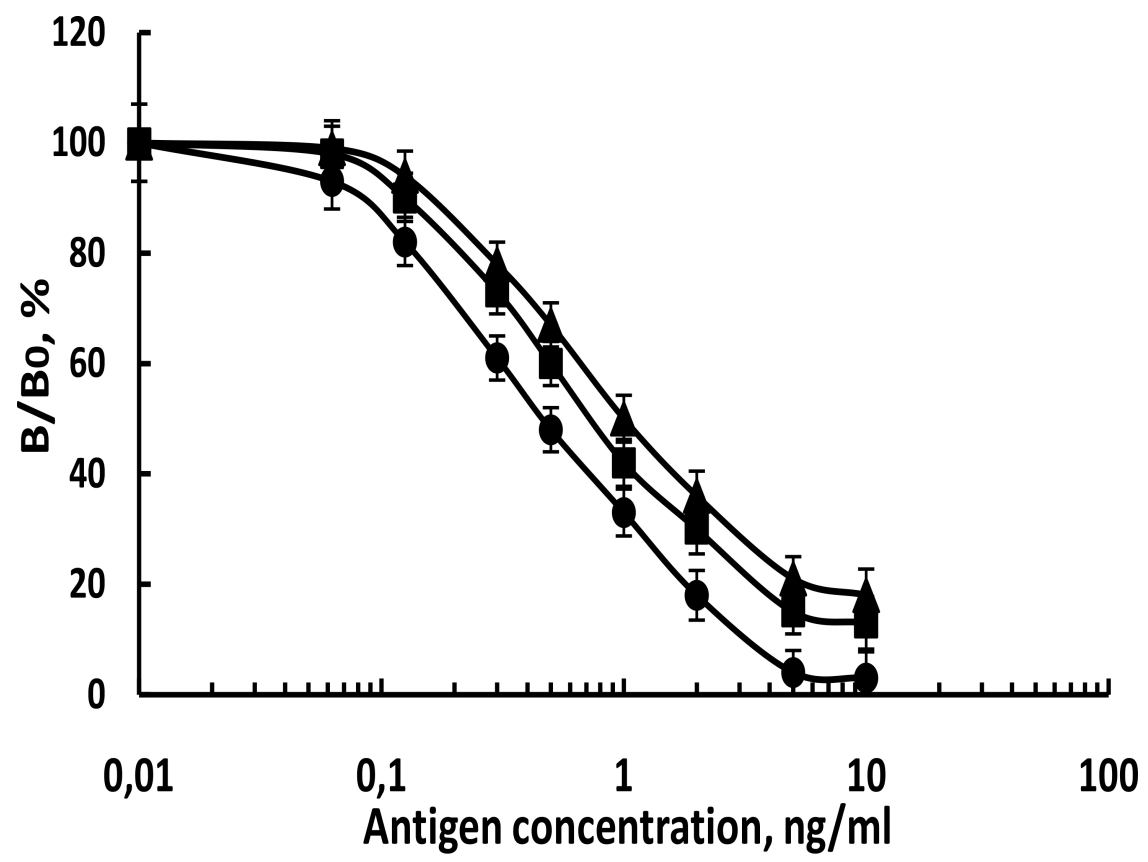

Fig (4). Calibration curves for determination of paraoxon and dichlorvos by MNPs-based ELISA: dichlorvos (•), paraoxon (匹), dichlorvos + paroxon with multi-antibody $(\boldsymbol{\Delta})$.

Table 1. Basic analytical characteristics of the MNPs-based ELISA to determine the concentration of dichlorvos and paraoxon in buffer.

\begin{tabular}{|c|c|c|c|c|c|}
\hline Methods & $\begin{array}{c}\text { Linear } \\
\text { Range, } \\
\mathbf{n g} / \mathbf{m L}\end{array}$ & Linear Equation & $\mathbf{R}^{2}$ & $\begin{array}{c}\text { LOD, } \\
\mathbf{n g} / \mathbf{m L}\end{array}$ & $\mathbf{C V}, \mathbf{\%}$ \\
\hline $\begin{array}{c}\text { dichlorvos } \\
\text { (with anti-dichlorvos) }\end{array}$ & $0.063-5$ & $\mathrm{y}=-21,2 \ln (\mathrm{x})+34,96$ & 0,9951 & 0.04 & 6.5 \\
\hline $\begin{array}{c}\text { paraoxon } \\
\text { (with anti-paraoxon) }\end{array}$ & $0.15-5$ & $\mathrm{y}=-20,91 \ln (\mathrm{x})+45,833$ & 0,9926 & 0.09 & 7.1 \\
\hline $\begin{array}{c}\text { paraoxon+dichlorvos } \\
\text { (with multi-antibody) }\end{array}$ & $0.15-5$ & $\mathrm{y}=-20,38 \ln (\mathrm{x})+51,98$ & 0,9963 & 0.08 & 7.5 \\
\hline
\end{tabular}

Table 2. Basic analytical characteristics of the conventional competitive ELISA to determine the concentration of dichlorvos and paraoxon in buffer.

\begin{tabular}{|c|c|c|c|c|}
\hline No & Antigen & $\begin{array}{c}\text { Linear } \\
\text { Range, } \\
\mathbf{n g} / \mathbf{m L}\end{array}$ & Limits of Detection, $\mathbf{n g} \mathbf{m L}$ & Coefficient of Variation, $\%$ \\
\hline $\mathbf{1}$ & $\begin{array}{c}\text { dichlorvos } \\
\text { (with anti-dichlorvos) }\end{array}$ & $0.01-5$ & 0.006 & 5.9 \\
\hline $\mathbf{2}$ & $\begin{array}{c}\text { paraoxon } \\
\text { (with anti-paraoxon) }\end{array}$ & $0.01-5$ & 0.008 & 6.2 \\
\hline $\mathbf{3}$ & $\begin{array}{c}\text { paraoxon+dichlorvos } \\
\text { (with multi-antibody) }\end{array}$ & $0.01-5$ & 0.009 & 6.7 \\
\hline
\end{tabular}

In our case the obtained results with multi-polyclonal antibodies in terms of quality match the individual antibodies. Other authors described that using a mixture of conjugates of type I and type II pyrethroids were prepared polyclonal antibodies against both types of pyrethroid insecticides [29]. The study revealed the best combination, which showed equally high sensitivities (IC50 values of about $0.02 \mathrm{mg} / \mathrm{mL}$ ) to both types of pyrethroids. The other authors described that this method requires the preparation of the antigen using a careful design, even so, the obtained polyclonal antibodies always had lower titer and also less sensitivity in the immunoassay, which might be due to the low coupling ratio of each antigen, or it might be due to antigenic competition [30]. Gao et al. reported [31] that magnetic particles $\left(\mathrm{Fe}_{3} \mathrm{O}_{4}\right)$ with size 30,150 and 300 $\mathrm{nm}$ showed a peroxidase mimetic reaction. After coating the nanoparticles with different compounds, this reaction is reduced about 3 times. The greatest reduction is when applying a coating of 3-aminopropyltriethoxysilane (APTES) and $\mathrm{SiO}_{2}$. 
After immobilization of an antibody on the MNPs, this reduction becomes even greater. In our case, when determining the experimental signal ( $\mathrm{Y}$ ) of the developed ELISA, if there is a background from peroxidase mimetic reaction, it is destroyed as it participates in the numerator and denominator in the following formula $-\mathrm{Y}=\mathrm{B} / \mathrm{B}$. However, to clarify whether this factor does not affect the assay, we used three different amounts of magnetic nanoparticles with immobilized antibody and subsequent blocking with BSA - 0.06, 0.125, and 0.25 $\mathrm{mg} / \mathrm{ml} . \mathrm{H}_{2} \mathrm{O}_{2}$ and TMB were added to these three amounts in the same amount as the developed MNPs-based ELISA. In all three samples, absorption measured at $15 \mathrm{~min}$ was found to be negligible, and did not change further over time. Therefore, in our case, no peroxidase mimetic reaction was detected.

The obtained results were compared with analogical results from other authors. Li et al. [32] developed ELISA for the determination of paraoxon-methyl with a working range $0.012-1.158 \mu \mathrm{g} / \mathrm{mL}$ and LOD - $5 \mathrm{ng} / \mathrm{mL}$. In other case LOD of parathion methyl using polyclonal antisera was $0.2 \mathrm{ng} / \mathrm{mL}$ [33] and with monoclonal antisera $0.08 \mathrm{ng} / \mathrm{mL}$ [34] using an indirect competitive ELISA. Xu et al. [35] described ELISA method for determination of parathion with LOD $2.9 \mathrm{ng} / \mathrm{mL}$ and Zhang et al. [36] determined LOD $0.048 \mu \mathrm{g} / \mathrm{mL}$ for dichlorvos. The obtained results showed that the developed MNPs-ELISA is a very sensitive method.

\subsection{Comparison of the Obtained Results Between MNPs- based ELISA and Conventional ELISA for Determination of Dichlorvos and Paraoxon}

A comparison of the developed modified MNPs-based ELISA with the conventional ELISA was performed. Three typical calibration curves were prepared for the analysis of dichlorvos and paraoxon with anti-dichlorvos, anti-paraoxon and multi-antibody by competitive ELISA. First, the optimal antibody concentrations $(50 \mu \mathrm{g} / \mathrm{mL})$ and hapten-OVA conjugate $(5 \mu \mathrm{g} / \mathrm{mL})$ were determined by checkerboard titration. The number of analyses at each concentration was six. The detection limit and the linear range of the dichlorvos and paraoxon determination with the corresponding antibodies are given in Table $\mathbf{2}$. It is obvious that the assays have close sensitivity and the same linear ranges of paraoxon, dichlorvos and the mixture of paraoxon and dichlorvos. When comparing the results from the conventional ELISA (Table 2) with the results obtained from the modified MNPs-based ELISA (Table 1), they were found to be close. The LOD in the conventional ELISA are lower, and the sensitivity of the assay is better. The reproducibility of the results for both analyzes is identical. There is a coincidence of the results about the types of pesticides. For both methods, the detection limit for dichlorvos is the lowest, for paraoxon and the simultaneous determination of paraoxon and dichlorvos, the results are the same.

\subsection{Recovery Determination of Dichlorvos and Paraoxon in Milk Samples by Developed MNPs Based ELISA and Conventional ELISA}

The developed MNPs-ELISA method and the conventional ELISA method were applied to determine the concentration of paroxon and dichlorvos in cows' milk with $3.5 \%$ fat. An assessment of the accuracy of the two methods was made in model solutions of dichlorvost and paraoxon in milk. Milk samples containing dichlorvos and paraoxon were prepared at concentrations of $0.1,0.5$, and $4 \mathrm{ng} / \mathrm{mL}$. The starting milk does not contain pesticides (proven by an Abraxis OP/Carbamate Assay Kit). It should be noted that it was not necessary to perform any sample pretreatment to the milk samples. Recovery values are shown in Table 3 . It can be seen that, the recovery of pesticides in milk samples in both methods was from 104 to $110 \%$. For only two samples with low pesticide concentration $(0.1 \mathrm{ng} / \mathrm{mL})$ the recovery was 110 and $115 \%$. Probably the matrix effect of the milk affected the results and gave recovery greater than $100 \%$. It was found that the assay has a high accuracy, Coefficient of Variation (CV) is less 10.

From the comparison of the two methods, it can be seen that the analytical characteristics are relatively close. However, the developed MNPs-based ELISA method is faster (45 minutes) than the conventional ELISA method (minimum 2 hours). The use of magnetic nanoparticles with high surface areas for immobilization of antibodies greatly improves the performance and rate of the immunological reaction and decreases the antibody immobilization time. The cited advantages of magnetic nanoparticles led to the development of an integrated method to provide a better sensitivity, short immobilization time, rapid analysis, and simple washing procedures.

Table 3. Recovery of dichlorvos and paraoxon in milk determined by developed MNPs-based ELISA and ELISA methods $(\mathbf{n}=6)$.

\begin{tabular}{|c|c|c|c|c|c|c|}
\hline \multirow[b]{2}{*}{ Antibody } & \multirow[b]{2}{*}{ Sample } & \multirow{2}{*}{$\begin{array}{l}\text { Added Concentration, } \\
\text { ng/mL }\end{array}$} & \multicolumn{2}{|c|}{ MNPs-based ELISA } & \multicolumn{2}{|l|}{ ELISA } \\
\hline & & & $\begin{array}{c}\text { Detected Concentration, } \\
\mathrm{ng} / \mathrm{mL}\end{array}$ & $\begin{array}{c}\text { Recovery, } \\
\%\end{array}$ & $\begin{array}{c}\text { Detected Concentration, } \\
\mathrm{ng} / \mathrm{mL}\end{array}$ & $\begin{array}{c}\text { Recovery, } \\
\%\end{array}$ \\
\hline \multirow{3}{*}{$\begin{array}{l}\text { Anti-dichlorvos } \\
\text { antibody }\end{array}$} & \multirow{3}{*}{ dichlorvos } & 0.1 & 0.115 & 115 & 0.11 & 110 \\
\hline & & 0.5 & 0.49 & 98 & 0.52 & 104 \\
\hline & & 4.0 & 4.3 & 107 & 4.20 & 105 \\
\hline \multirow{3}{*}{ Anti-paraoxon } & \multirow{3}{*}{ paraoxon } & 0.1 & 0.09 & 90 & 0.113 & 110 \\
\hline & & 0.5 & 0.51 & 102 & 0.53 & 106 \\
\hline & & 4.0 & 4.3 & 107 & 4.40 & 107 \\
\hline \multirow{3}{*}{ Multi-Antibody } & \multirow{3}{*}{$\begin{array}{l}\text { dichlorvos } \\
+ \text { paraoxon }\end{array}$} & 0.1 & 0.11 & 110 & 0.115 & 115 \\
\hline & & 0.5 & 0.51 & 102 & 0.53 & 106 \\
\hline & & 4.0 & 3.8 & 95 & 4.30 & 107 \\
\hline
\end{tabular}


3.6. Validation of the MNPs-based ELISA for the Determination of Pesticides in Real Samples. Matrix Effect of the Samples

The effect of protein, $\mathrm{pH}$, and fat in milk samples on the analytical characteristics of the MNPs-based ELISA was investigated. Typically, the $\mathrm{pH}$ of the milk is from 5 to 6.6 and has no impact on immunoassay. Only fat above $4.5 \%$ has been found to have a significant impact on immunological analysis. Normally, the fat concentration in cow's milk is $3.5-4 \%$. Therefore, no interference data is displayed. The obtained results confirm the potential of the new MNPs-based ELISA immunoassay for the quantification of individual and a mixture of dichlorvos and paraoxon in milk samples.

In order to validate the results obtained from the MNPsbased ELISA method, experiments were performed by HPLC. Samples of milk containing $0.5 \mathrm{ng} / \mathrm{mL}$ dichlorvos and paraoxon in ratio (1:1) were used. The recovery of the samples was calculated for the two methods. The obtained recovery values in the chromatographic method range from 92 to $99 \%$. They are slightly lower than those obtained by MNPs-based ELISA (104-110\%). It has been found that the obtained results of pesticides in milk using MNPs-based ELISA and high performance liquid chromatography are similar. The main advantage of MNPs-based ELISA is that it allows the analysis of a large number of samples without using extraction and concentration of pesticide residues, such as those required for chromatographic methods. Frequent routine analyzes can safely be done using this simpler and cheaper method without losing either reliability or accuracy.

\section{CONCLUSION}

A sensitive and rapid MNPs-based ELISA for the individual and simultaneous determination of dichlorvos and paraoxon directly in untreated milk was developed. Conventional ELISA methods are highly sensitive but take a long time (at least 2 hours), because multiple washings are required to remove unbound components. Combination of magnetic nanoparticles with ELISA leads to the reduction of assay time. The use of a magnetic field, allows easy separation of the magnetic nanoparticles-immunoconjugates from the nonbound competitive conjugate in the sample. The use of multipolyclonal antibodies permits simultaneous determination of dichlorvos and paraoxon in milk sample. The MNPsimmunoassay demonstrated to be able to detect multiple pesticides accurately even in whole milk samples.

\section{ETHICS APPROVAL AND CONSENT TO PARTICIPATE}

Not applicable.

\section{HUMAN AND ANIMAL RIGHTS}

No animals/humans were used for studies of this research.

\section{CONSENT FOR PUBLICATION}

Not applicable.

\section{AVAILABILITY OF DATA AND MATERIAL}

Not applicable.

\section{FUNDING}

The authors thank the Bulgarian National Science Fund at the Ministry of Education for the financial support within the framework of the Bulgarian-Russian project 02/10-2018.

\section{CONFLICT OF INTEREST}

The author declares no conflict of interest, financial or otherwise.

\section{ACKNOWLEDGEMENTS}

Declared none.

\section{REFERENCES}

[1] Ambrus Á, Yang YZ. Global harmonization of maximum residue limits for pesticides. J Agric Food Chem 2016; 64(1): 30-5. [http://dx.doi.org/10.1021/jf505347z] [PMID: 25603277]

[2] Pehkonen O, Zhang Q. The degradation of organophosphorus pesticides in natural waters: A critical review. Crit Rev Environ Sci Technol 2002; 32: 17-72.

[http://dx.doi.org/10.1080/10643380290813444]

[3] Maftouh A, Moussaif A. Synthesis of haptens for immunoassay of Chlorpyrifos-ethyl as organophosphorus pesticides. JMES 2017; 8(3): 878-3.

[4] Hua X, Yang J, Wang L, Fang Q, Zhang G, Liu F. Development of an enzyme linked immunosorbent assay and an immunochromatographic assay for detection of organophosphorus pesticides in different agricultural products. PLoS One 2012; 7(12)e53099 [http://dx.doi.org/10.1371/journal.pone.0053099] [PMID: 23300869]

[5] Bhadekar R, Pote S, Tale V, et al. Developments in analytical methods for detection of pesticides in environmental samples. Am J Anal Chem 2011; 2: 1-15.

[http://dx.doi.org/10.4236/ajac.2011.228118]

[6] Bavcon M, Trebse P, Zupancic-Kralj L. Investigations of the determination and transformations of diazinon and malathion under environmental conditions using gas chromatography coupled with a flame ionisation detector. Chemosphere 2003; 50(5): 595-601. [http://dx.doi.org/10.1016/S0045-6535(02)00643-4] 12685735]

[7] Yang JY, Xu ZL. Immunochemical techniques for multianalyte analysis of chemical residues in food and the environment: A review. Trends in Analytical Chemistry 2017; 88: 25-40.

[8] Wang ST, Gui WJ, Guo YR, Zhu GN. Preparation of a multi-hapten antigen and broad specificity polyclonal antibodies for a multiple pesticide immunoassay. Anal Chim Acta 2007; 587(2): 287-92. [http://dx.doi.org/10.1016/j.aca.2007.01.052] [PMID: 17386785]

[9] Liang Y, Liu XJ, Liu Y, Yu XY, Fan MT. Synthesis of three haptens for the class-specific immunoassay of $O, O$-dimethyl organophosphorus pesticides and effect of hapten heterology on immunoassay sensitivity. Anal Chim Acta 2008; 615(2): 174-83. [http://dx.doi.org/10.1016/j.aca.2008.03.050] [PMID: 18442523]

[10] Hua X, Wang L, Li G, et al. Multi-analyte enzyme-linked immunosorbent assay for organophosphorus pesticides and neonicotinoid insecticides using a bispecific monoclonal antibody. Anal Methods 2013; 5: 1556-63.

[http://dx.doi.org/10.1039/c3ay26398c]

[11] Cui X, Jin M, Du P, et al. Development of immunoassays for multiresidue detection of small molecule compounds. Food Agric Immunol 2018; 29(1): 638-52

[http://dx.doi.org/10.1080/09540105.2018.1428284]

[12] Xu ZL, Zeng DP, Yang JY, et al. Monoclonal antibody-based broadspecificity immunoassay for monitoring organophosphorus pesticides in environmental water samples. J Environ Monit 2011; 13(11): 3040-8.

[http://dx.doi.org/10.1039/c1em10331h] [PMID: 21915424]

[13] Liu Y, Guo Y, Zhu G, Tang F. Enzyme-linked immunosorbent assay for the determination of five organophosphorus pesticides in camellia oil. J Food Prot 2014; 77(7): 1178-83. 
[http://dx.doi.org/10.4315/0362-028X.JFP-13-465] [PMID: 24988025]

[14] Watanabe E, Miyake S, Yogo Y. Review of enzyme-linked immunosorbent assays (ELISAs) for analyses of neonicotinoid insecticides in agro-environments. J Agric Food Chem 2013; 61(51): 12459-72.

[http://dx.doi.org/10.1021/jf403801h] [PMID: 24295127]

[15] Williams KJ, Thorpe SA, Reynolds SL. The use of ELISA for the determination of pesticide residues in food. Int J Environ Anal Chem 1996; 65: 149-52.

[http://dx.doi.org/10.1080/03067319608045550]

[16] Yamasaki T, Inoue T, Hirakawa Y, Miyake S, Ueno E, Saito I. Validation of ELISA kits for pesticide residue analysis in vegetables and fruits. Shokuhin Eiseigaku Zasshi 2015; 56(6): 240-6.

[http://dx.doi.org/10.3358/shokueishi.56.240] [PMID: 26699271]

[17] Liu B, Gong H, Wang Y, et al. A gold immunochromatographic assay for simultaneous detection of parathion and triazophos in agricultural products. Anal Methods 2018; 10: 422-8.

[http://dx.doi.org/10.1039/C7AY02481A]

[18] Ha Y, Ko S, Kim I, et al. Recent advances incorporating superparamagnetic nanoparticles into immunoassays. ACS Appl Nano Mater 2018; 1(2): 512-21.

[http://dx.doi.org/10.1021/acsanm.7b00025] [PMID: 29911680]

[19] Vallabani NVS, Singh S. Recent advances and future prospects of iron oxide nanoparticles in biomedicine and diagnostics. Biotech 2018; 8(6): 279-89.

[20] Zhang X, Wang X, Sun M, et al. A magnetic nanoparticle based enzyme-linked immunosorbent assay for sensitive quantification of zearalenone in cereal and feed samples. Toxins (Basel) 2015; 7(10): 4216-31.

[http://dx.doi.org/10.3390/toxins7104216] [PMID: 26492271]

[21] Urusov AE, Petrakova AV, Vozniak MV, Zherdev AV, Dzantiev BB. Rapid immunoenzyme assay of aflatoxin B1 using magnetic nanoparticles. Sensors (Basel) 2014; 14(11): 21843-57. [http://dx.doi.org/10.3390/s141121843] [PMID: 25412219]

[22] Yao M, Wang L, Fang C. The chemiluminescence immunoassay for aflatoxin B1 based on functionalized magnetic nanoparticles with two strategies of antigen probe immobilization. Luminescence 2017; 32(4): 661-5.

[http://dx.doi.org/10.1002/bio.3235] [PMID: 27767254]

[23] Wang YK, Wang YC, Wang HA, et al. An immunomagnetic-beadbased enzyme-linked immunosorbent assay for sensitive quantification of fumonisin B1. Food Control 2014; 40: 41-5. [http://dx.doi.org/10.1016/j.foodcont.2013.11.025]

[24] Xu F, Ren K, Yang Y, et al. Immunoassay of chemical contaminants in milk: A review. J Integr Agric 2015; 14(11): 2282-95. [http://dx.doi.org/10.1016/S2095-3119(15)61121-2]

[25] Akhtar S, Ahad K. Pesticides residue in milk and milk products: Mini review. Pak J Anal Environ Chem 2017; 18(1): 37-45. [http://dx.doi.org/10.21743/pjaec/2017.06.03]

[26] Gabrovska K, Ivanova S, Ivanov Y, et al. Immunofluorescent analysis with magnetic nanoparticles for simultaneous determination of antibiotic residues in milk. Anal Lett 2013; 46: 1537-52.

[http://dx.doi.org/10.1080/00032719.2013.769264]

[27] Yaneva MY, Ivanov YL, Godjevargova TI. Preparation of polyclonal antibodies with application for an organophosphorus pesticide immunoassay. Anal Lett 2017; 50(8): 1307-24.

[http://dx.doi.org/10.1080/00032719.2016.1221417]

[28] Bradford MM. A rapid and sensitive method for the quantitation of microgram quantities of protein utilizing the principle of protein-dye binding. Anal Biochem 1976; 72: 248-54.

[http://dx.doi.org/10.1016/0003-2697(76)90527-3] [PMID: 942051]

[29] Zhang Q, Zhang W, Wang X, Li P. Immunoassay development for the class-specific assay for types I and II pyrethroid insecticides in water samples. Molecules 2010; 15(1): 164-77.

[http://dx.doi.org/10.3390/molecules15010164] [PMID: 20110881]

[30] Li YF, Sun YM, Beier RC, et al. Immunochemical techniques for multianalyte analysis of chemical residues in food and the environment: A review. Trends Analyt Chem 2017; 88: 25-40. [http://dx.doi.org/10.1016/j.trac.2016.12.010]

[31] Gao L, Zhuang J, Nie L, et al. Intrinsic peroxidase-like activity of ferromagnetic nanoparticles. Nat Nanotechnol 2007; 2(9): 577-83. [http://dx.doi.org/10.1038/nnano.2007.260] [PMID: 18654371]

[32] Li ZK, Zhu YY, Yin XG, et al. Development of an indirect enzymelinked immunosorbent assay for the organophosphorus pesticide paraoxon-methyl. Immunol Invest 2009; 38(6): 510-25.

[http://dx.doi.org/10.1080/08820130902803689] [PMID: 19811409]

[33] Kolosova A, Park J, Eremin S, et al. Comparative study of three immunoassays based on monoclonal antibodies for detection of the pesticide parathion-methyl in real samples. Anal Chim Acta 2004; 511: 323-31.

[http://dx.doi.org/10.1016/j.aca.2004.01.047]

[34] Kim MJ, Lee HS, Chung DH, Lee YT. Synthesis of haptens of organophosphorus pesticides and development of enzyme-linked immunosorbent assays for parathion-methyl. Anal Chim Acta 2003; 493: 47-62.

[http://dx.doi.org/10.1016/S0003-2670(03)00793-1]

[35] Xu ZL, Shen YD, Zheng WX, et al. Broad-specificity immunoassay for O,O-diethyl organophosphorus pesticides: Application of molecular modeling to improve assay sensitivity and study antibody recognition. Anal Chem 2010; 82(22): 9314-21.

[http://dx.doi.org/10.1021/ac1018414] [PMID: 20958019]

[36] Tang J, Zhang M, Cheng G, Li A, Lu Y. Development of IC-ELISA for detection of organophosphorus pesticides in water. J Environ Sci Health B 2008; 43(8): 707-12.

[http://dx.doi.org/10.1080/03601230802388827] [PMID: 18941995]

\section{(C) 2019 Yavor Ivanov.}

This is an open access article distributed under the terms of the Creative Commons Attribution 4.0 International Public License (CC-BY 4.0), a copy of which is available at: (https://creativecommons.org/licenses/by/4.0/legalcode). This license permits unrestricted use, distribution, and reproduction in any medium, provided the original author and source are credited. 